\title{
BIOSTRATIGRAPHY, MICROFACIES ANALYSIS AND SEQUENCE STRATIGRAPHY OF THE MIOCENE SUCCESSIONS IN CAIRO-SUEZ DISTRICT, EGYPT
}

\author{
Abdel Galil A.Hewaidy*, Mohamed W.Abd El-Moghny*, Haitham M.Ayyad*, Osama Gameel* \\ *Geology Department, Faculty of Science, Al-Azhar University, Nasr City, Cairo, Egypt
}

\begin{abstract}
Two Miocene sections in Cairo-Suez district at Tall Zamzam and Wadi Hommath are detailed examined for their foraminiferal, nannofossil contents and microfacies types. Wadi Hommath section is named as the Sadat Formation, while Tall Zamzam section is named as the Genefe Formation. 21 species of planktonic, 20 species of benthic, 19 species of nannofossils are identified. Two zones of planktonic foraminifera and one zone of nannofossil attributed the Sadat Formation to Globigerinoides bisphericus (M4) Zone, Praeorbulina sicana (M5a) Zone and Genefe Formation to Praeorbulina glomerosa (M5b) Zone, while Helicosphaera ampliamperta Zone (NN4) of (Burdigalian-Langhian) age is recorded in the two studied secions. The identified benthic foraminifera was used to recognize three biofacies types: Nonion biofacies of inner-shelf environment, Cibicides biofacies of middle-shelf environment and Uvigerina biofacies of outer-shelf environment. Six microfacies types are identified. These successions are subdivided into three depositonal sequences of which 2 fourth order and one third order sequences.
\end{abstract}

Keywords: Foraminifera, nannoplankton, sequence stratigraphy, Miocene, Cairo-Suez district, Egypt.

\section{INTRODUCTION}

The exposed rock units in Cairo-Suez district fall within a span of time beginning with the Late Early Eocene in the east followed westward by other different rock units of Eocene, Oligocene and Miocene time units. 36 representative rock samples were collected from these sections as follows: 13 rock samples from Wadi Hommath, 23 rock samples from Tall-Zamzam (Fig. 1). The Paleocene sediments are totally missing or not exposed in the study area. These encountered rock units were greatly influenced by the events which prevailed over the Red Sea and Gulf of Suez regions during the late stage of the Eocene and continued to the Late Miocene (Patton et al.1994). The most common event was the Gulf of Suez rifting, which resulted in the displacement of many blocks relatively to each other giving rise to a complex stratigraphic setting on both sides of the Gulf (Steckler et al. 1988; Issawi 2002, 2005; Osman 2003; Issawi et al. 2009).

\section{MATERIALS, METHODS DEPOSITORY}

AND

Two stratigraphic Miocene sections along Cairo-Suez district were measured at Wadi
Hommath towards east, and Tall Zamzam towards west. To describe the sedimentary structures and microfacies types of the studied succession, 13 petrographic thin sections from the calcareous units were examined (e.g. sandy limestones; Fig. 2). A standard petrographic microscope equipped with a digital camera was used to qualitatively identify the microfossils in the thin sections. Microfacies analysis was carried out using the standard models of Wilson (1975) and Flugel (2010). The texture of the carbonate rocks was described based on Dunham's classification scheme (1962), as refined by Embry and Klovan (1971). The mixed siliciclastic-carbonate rocks were characterized using the principles proposed in the classification of Mount (1985). Microfacies classification was carried out by the combined analysis of the mineralogical components, macro- and microfossil assemblages, and textures of the samples observed in the thin sections. The sequence stratigraphic interpretation is based upon bounding surface characteristics, vertical cycle stacking patterns and variations in the depositional facies and their interpreted environments.The identified forminifera as well as nannofossils are deposited in the collection of Prof. Abd el Galil Hewaidy, Azhar University, Faculty of Science. 


\section{LITHOSTRATGRAPHY}

The Neogene sediments are exposed in Cairo-Suez district at Tall Zamzam, Wadi Ghoweiba, Wadi Hagul, and to the north at Gebel Iweibed, Gebel Homeiyra, and Gebel Gharra. The central part of the Cairo-Suez district consists of a nearly parallel, high mountain ridges trending in an E-W and NWSE directions with lowlands in-between. The Middle Eocene and Miocene rocks mainly build the mountains and high scarps overlooking both sides of the Qattamiya-Ain Sukhna road, while both the Upper Eocene and Oligocene sediments fill the low topographic areas. The Miocene sequence in the studied stratigraphic sections is characterized by considerable lateral facies changes from east to west of the Cairo-Suez district. These rock units belong to the Early and Middle Miocene and represented by Sadat, Gharra (Early Miocene), Hommath and Genefe (Middle Miocene).

\section{Sadat Formation}

The Sadat Formation named by Abdallah and Abdelhady (1966) at Wadi El Ramiya, Sadat Quarry, Suez-Sukhna district and assigned it an early Miocene (Burdigalian) age. the Sadat Formation measures $98 \mathrm{~m}$ in thickness and overlies unconformably the Eocene strata and underlies the Middle Miocene Hommath Formation. According to Cherif and Yehia (1977), it can be subdivided into the Taratir member at base and Quarry member at top. The Sadat Formation, as a lower subdivision of the Miocene succession, exclusively occupies the northeastern reach of the studied area. The formation also crops out in the upper reach of Wadi Hagul. It transgressively overlaps either the Middle or Upper Eocene rocks and is downlaped westward by the younger Miocene rocks.

In the studied area, the Sadat Formation has been measured and described at Wadi Hommath area. It attains about $13 \mathrm{~m}$ thick and consists of white to pale yellow limestone intercalated by yellowish brown, fine to coarse calcareous sandstone (Fig.2). These sandstones are intercalated by shale at the base, and shell bed of sandy fossiliferous limestone at the top. The shell beds are commonly formed of large, thick-shelled oysters including Ostrea sp

\section{Genefe Formation}

The name Genefe Member was first used by Ghorab and Marzook (1965) to describe the uppermost limestone beds $(\mathrm{ca} \approx 68.5 \mathrm{~m}$ thick) of the Genefe Formation at Gebel Genefe, west of the Suez Canal. Said (1990) raised this unit to formational rank and assigned it to the middle Miocene (Langhian) age. The Genefe Formation in the present study is measured and described at Tall Zamzam section (Fig. 3). It is made up of yellowish white to snow white algal limestone (about $23 \mathrm{~m}$ thick) that is unconformably overlain by the upper Miocene non-marine sediments. The lower part of the Genefe Formation at Tall Zamzam section is measured and described along several trenches. It is composed of yellow, massive, argillaceous limestone rests on yellowish brown,planner cross-bedded, fine to coarse grained sandstone, medium grained calcareous sandstone with mudstone intercalations at the base (Fig. 3,4). These deposits overlie unconformably the Oligocene weathered basalt and reddish brown, gravely sandstones.

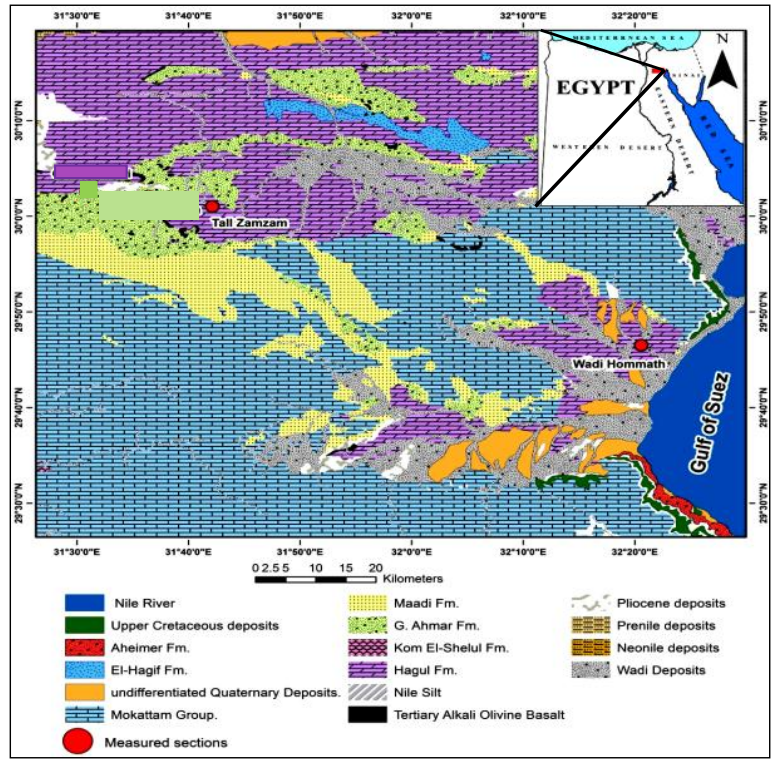

Figure 1: Geological map of Cairo-Suez district, showing the location of the measured sections (modified after Conoco, 1987). 


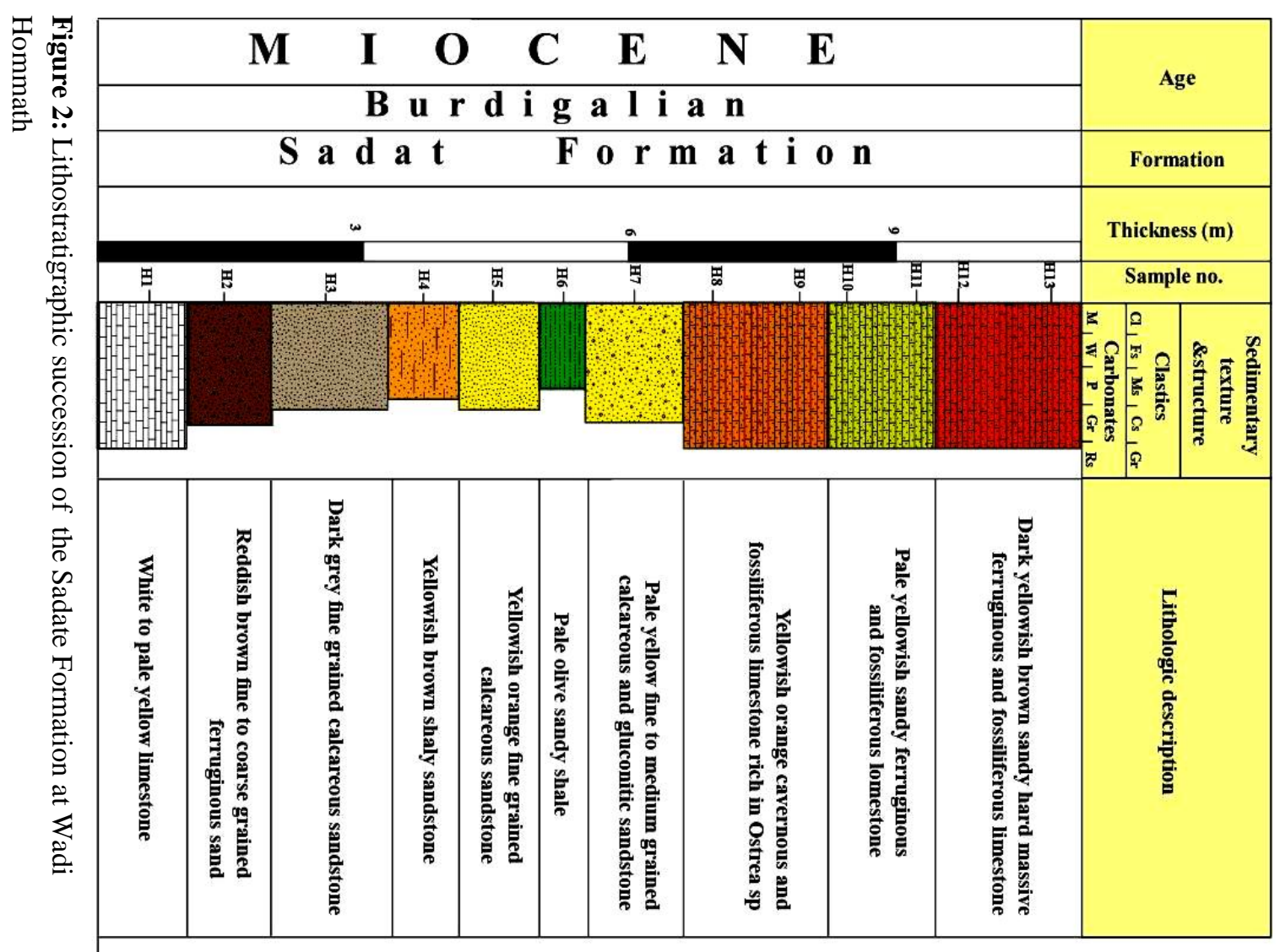

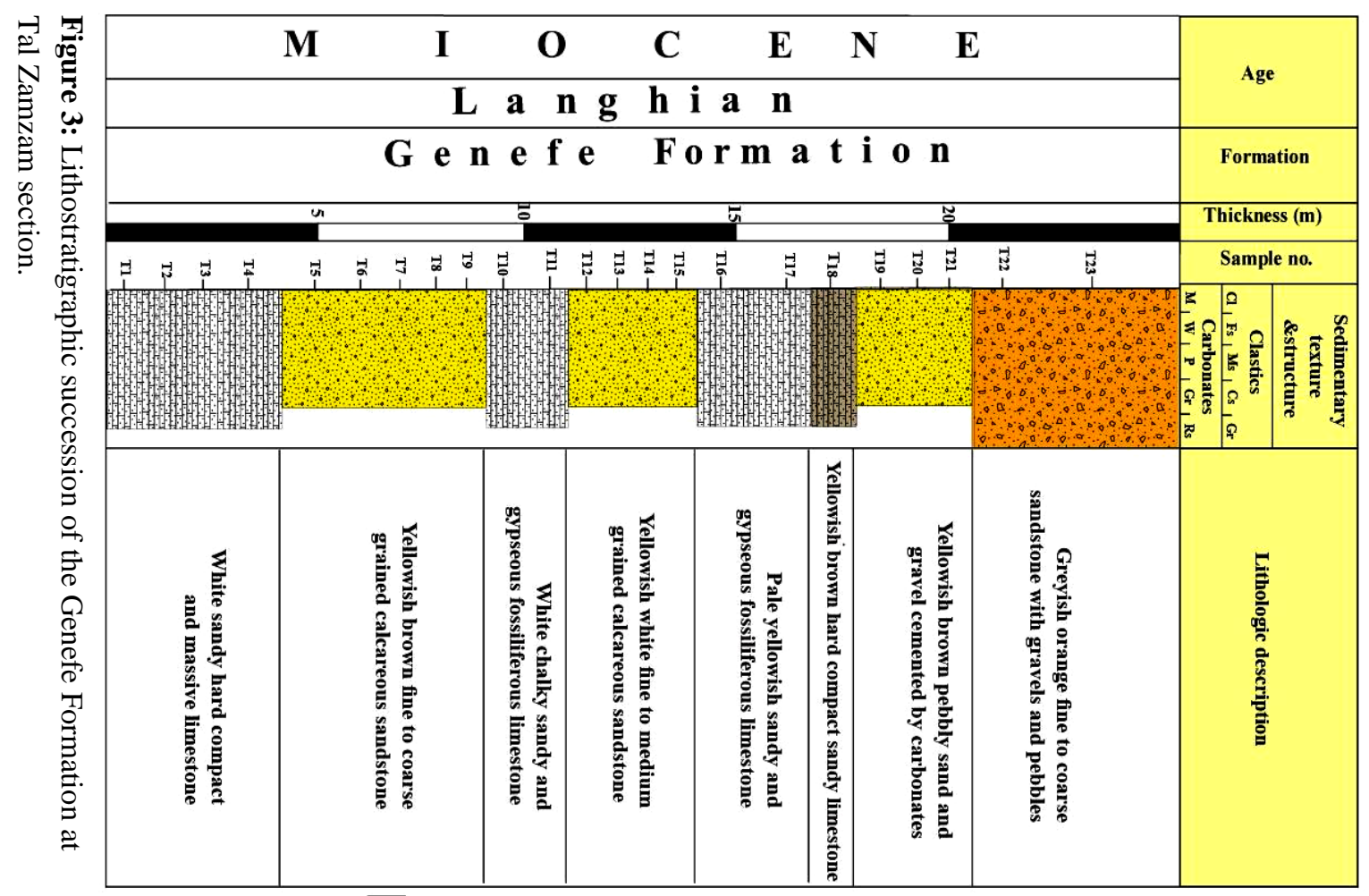



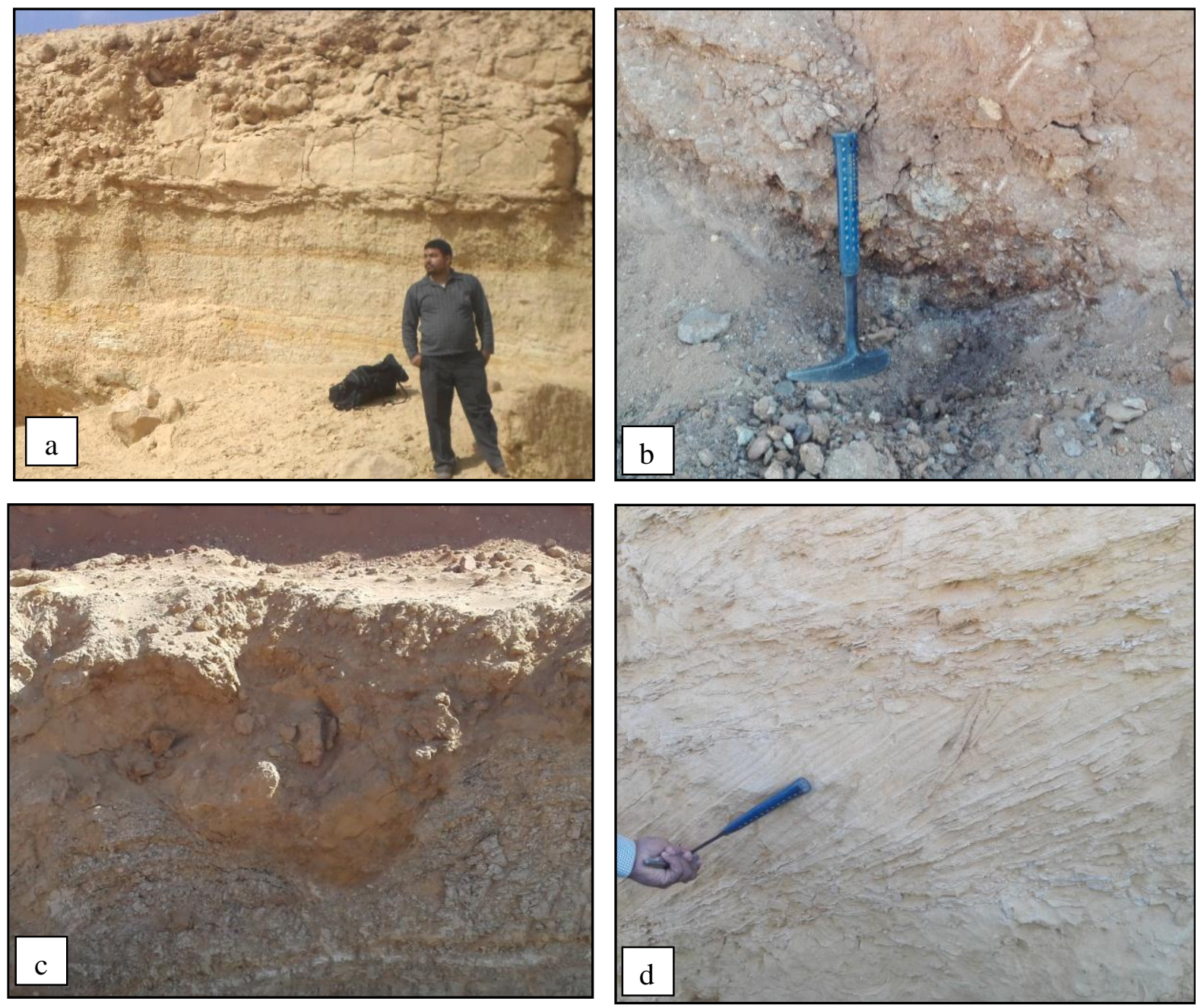

Figure 4: Field photographs showing lithological characteristics of the studied Miocene successions: a) sandstones alternating with shales and limestones of the Sadat Formation at Wadi Hommath section; b) contact between the Oligocene weathered basalt and overlying Miocene deposits at Tall Zamzam area; c) sandstone intercalated by mudstone of Genefe Formation at Tall Zamzam section; d) planner cross-bedded sandstone with ichno sedimentary structures in the lower part of the Genefe Formation at Tall Zamzamy section.

\section{RESULTS AND INTERPRETATION}

\subsection{Microfacies analysis}

The Miocene successions in Cairo Suez district display a cyclic sedimentation and relatively rapid laesteral facies change. This change may be related to deposition on an irregular shelf with submerged structural highs and lows. Consequently, the aim of the microfacies analysis is to integrate sedimentological and paleontological results to appraise the depositional history of the Lower and Middle Miocene sections in the study area.

13 thin sections are prepared and six microfacies types have been determined from the studied sections by using field observation, mineralogical components, macrofossil and microfossil assemblages, and texture of the examined samples. These microfacies types are represented by three carbonate microfacies and three siliciclastic facies types. The identified carbonate microfacies are: 1 . Sandy dolostone; 2. Sandy algal bioclastic packstone/grainstone; and 3. Sandy wackestone. Furthermore, the siliciclastic facies types are represented by calcareous quartz arenite, quartz arenite and mudstone. In the following paragraphs, the description and interpretation of the different microfacies types are deciphered, with an emphasis on their depositional environments. 


\section{i. Sandy dolostone}

This microfacies type is recorded in the upper part the Genefe Formation at Tall Zamzam and the middle parts of the Sadat Formation at Hommath section (samples No. T18, T22 and $5 \mathrm{H}$ respectively). It is made up of yellowish orange, very hard, highly fossiliferous, sandy dolostone. Microscopically it is characterized by fine subangular to subrounded, moderately sorted quartz grains forming about $30-35 \%$ of the rock (Fig.5A). These quartz grains are scattered in a diagenitic dolomite groundmass with relics of micrite matrix. Dolomite crystals range from euhedral (idiotopic) to subhedral (hypedotopic), polymodal, rhombic textures and originated from recrystallization of calcite matrix. The predominance of fine quartz grains and micrite matrix reflect slightly quite, shallow neritic depositional environment of this microfacies.

\section{ii. Sandy algal bioclastic packstone/grainstone}

This microfacies is recorded in several intervals of the Genefe Formation at Tall Zamzam section and made up of white to pale yellow, semi-hard to hard, less compact to compact, fossiliferous, sandy limestone. Allochems form $\approx 70-80 \%$ of this microfacies type and composed mainly of algae (Lithothamnium sp.) with few echinoid shell fragments. Although these algal fossils are made up of cryptocrystalline calcite, some algal parts are recrystallized and formed of microsparite. The non-carbonate particles (about $15 \%$ of the rock) are represented by fine to medium, subrounded to subangular, ill sorted quartz grains (Fig. 5B). Shell fragments are increased in size upwardly, carbonate matrix and glauconite content can be noted in the studied Tall Zamzam section. Different grains are scattered in fine cryptocrystalline micrite matrix that partially recrystallized and neomorphozed to spary calcite. Enrichment of red algal shell fragments and fine carbonate matrix and depletion of siliciclastic input denote quite inner neritic depositional environment of this studied microfacies.

\section{iii. Sandy wackestone}

This microfacies type is recorded in the lower part of the Genefe Formation in Tall Zamzam section (sample -3/2, 1/2,3/2). This microfacies type consists of grayish white, massive, semi-hard, sandy limestone. Allochems of this microfacies are represented by coarse to medium, moderately sorted, quartz grains (up to 15\%) and algal bioclastic fragments (about 5\%) scattered in cryptocrystalline calcite matrix (up to $85 \%$ of the rock) (Fig.5C). This microfacies type is characterized by small fenestral cavities or birdseyes microstructure. These cavities are filled with sparry calcite cement. Predominance of calcite matrix with birdseyes microstructure and the paucity of quartz and algal grains reflect a restricted intertidal-supratidal depositional environment.

\section{iv. Calcareous quartz arenite}

This sandstone facies type is recorded in the lower part of both Genefe and Sadat formations at Tall Zamzam and Wadi Hommath sections respectively (samples No. 3T, 4T and $4 \mathrm{H}$ respectively) and made up of moderately hard, grayish yellow to yellow, fine to coarse grained sandstones. It is characterized by subrounded to subangular, occasionally rounded, moderately to poorly sorted quartz grains that form $\approx 65 \%$ of the rock. Green, rounded glauconitic pellets are well developed in this sandstone type at the Sadat Formation forming about 7-10 \% of the rock (Fig.5D). Few $(<5 \%)$ feldspar grains (plagioclase and microcline) can be observed. All of these grains are cemented by microcrystalline calcite (microsparite) and/or iron oxides. The dominance of moderately sorted quartz grains, glauconitic pellets and microcrystalline calcite cement reflects an intertidal to shallow inner neritic depositional environments.

\section{v. Quartz arenite}

This microfacies type is recorded in the lower part of the Genefe Formation at Tall Zamzam section (sample $-1 / 1,3 / 1,6 / 1$ ). It is composed of pale yellow, medium to fine, 
semi-hard and planner cross-bedded sandstone intercalated with mudstone thin lenses. At the Genefe Formation this sandstone type of facies overlies weathered basalt and red sandstone of Oligocene age. Microscopically, this sandstone type of facies is made up of medium to fine sand (main size is $0.6 \mathrm{~mm}$ ), moderately sorted, monocrystalline, occasionally polycrystalline, sub-angular, elongated to spherical quartz grains occupying $>95 \%$ of the sample in an open backing texture (Fig.5E). Few $(<5 \%)$ rock fragments and feldspar grains can be observed in this facies type (Fig.5F). The dominance of moderately sorted quartz grains and planner cross-bedding of this facies type reflect an intertidal depositional environment.

\section{vi.. Mudstone}

This microfacies type is recorded in several stratigraphic intervals of the Genefe Formation at Tall Zamzam section (Fig. 4C). It is composed of variegated dark yellow, paleolive, grey and ferruginous mudstone with gypsum vienlets. Laboratory analysis revealed absence of fossil content in this facies type. This microfacies can be deposited in a quiet, restricted, shallow, inner neritic platform environment with low-energy conditions. The paucity of fauna reflects the deposition under low-oxygen water conditions and/or high argillaceous input during the deposition.

\subsection{Biostratigraphy}

\subsubsection{Biostratigraphy and age model}

Rare planktonic diagnostic microfossils are recorded in the Miocene units in Cairo-Suez area. No previous works touched this topic. The high- resolution biostratigraphy based on planktonic foraminifera and nannofossils in the Sadat Formation of Wadi Hommath section and the Genefe Formation of Tall Zamzam section. Quantitative analyses of selected calcareous nannofossil and planktonic foraminiferal species were used to determine the placement of the biozonal boundaries in the studied successions.

Both planktonic foraminifera and calcareous nannoplankton are useful tools for high-resolution biostratigraphy which are used in the present study. However, these assemblages of study area provide a comprehensive biostratigraphic framework for the early-middle Miocene succession. Consequently, they are suitable for chronostratigraphic correlation in this region. Moreover, planktonic foraminifera and calcareous nannofossils are the most extensively used biotic taxa for long-distance biostratigraphic correlation of marine strata. The results of biostratigraphic analysis from treated samples of the study area led to the identification of 21 species belonging to 9 genera of planktonic foraminifera and 19 species belonging to 10 genera of calcareous nannoplankton. The distribution charts of these species were shown on figures 6 and 7 .

The Early-Middle Miocene standard and widely used biostratigraphic zonal schemes are adopted here for planktonic foraminifera (e.g. Bolli, 1957; Blow, 1979; Berggren et al., 1995; Berggren and Pearson, 2005; Wade et al., 2011) and for calcareous nannoplankton (e.g. Martini, 1971; Okada and Bukry, 1980; Agnini et al., 2014). The presented biostratigraphy of the measured sections is based on the ranges and assemblages of calcareous nannoplankton and planktonic foraminiferal datum events.

\section{a.Planktonic foraminiferal biozones}

The Miocene planktonic foraminiferal biozones at the study area are arranged from base to top as follows: Zone M4 (Globigerinoides bisphericus Partial Range Zone), Zone M5a (Praeorbulina sicana Lowest-Occurrence Subzone) and Zone M5b ( Praeorbulina glomerosa Lowest-Occurrence Subzone).

i- The Globigerinoides bisphericus PartialRange Zone (M4)

This subzone was defined by Berggren and Pearson (2005) as the partial (range of the nominate taxon between the $\mathrm{HO}$ of Catapsydrax dissimilis (Cushman and Bermudez) and the LO of Praeorbulina sicana (Di Stefani).This interpretation is based 
on the HO of Catapsydrax dissimilis (Cushman and Bermudez) and co-occurance of Globigerinoides bisphericus (Todd). This zone corresponds to Zone N7 of Blow (1969, 1979) in extent, if not intent, and to the lowerpart of the Globigerinatella insueta
Interval Range Zone of Cushman and Stainforth 1945; as emended by Bolli, 1957b. apperance of Globigerinoides bisphericus (Todd) (Berggen et al.,1995). This Zone (M4) is defined as the interval between the Lowest Occurence (LO) of Globorotalia semivera
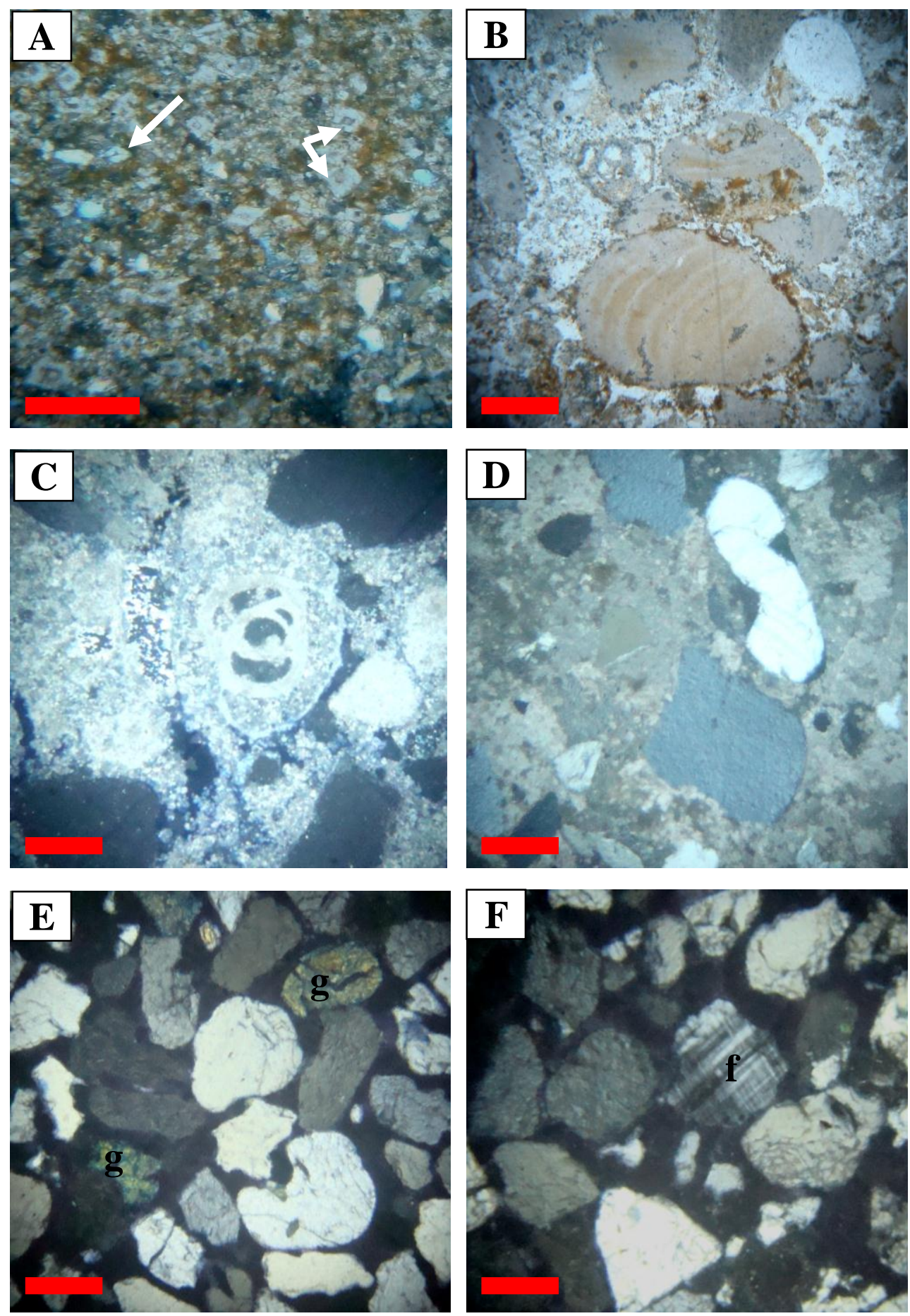

Figure 5: Photomicrographs showmicrofacies types of the studied Miocene deposits: A) sandy dolostone microfacies with euhedral dolomite crystals (arrows) with traces of micrite matrix; B) sandy algal bioclastic packstone/grainstone; C) sandy wackestone; D) calcareous quartz arenite; E,F) quartz arenite facies type with traces of glauconitic (g) and feldspar (f) grains. Bar scale $=0.5 \mathrm{~mm}$. 
(Hornibrook) and the Lowest Occurence (LO) of Globigerinoides trilobus (Reuss) and the first common occurrence of Globigerinoides bisphericus (Todd). Additional events are employed to support the zonal assignment of the lower part of the Sadat Formation to M4 Zone. These are: the co-occurrence of Globigerinoides bisphericus with Globigerinoides trilobus. In Egypt, this zone is equivalent to the $C$. dissimilis/Praeorbulina sicana (M4) Zone recorded by Hewaidy et al. (2013) and to the G. trilobus Zone which was recorded by many authors (Haggag et al., 1990; Phillip et al., 1997; Mandur 2004).

ii- The Praeorbulina sicana LowestOccurrence Subzone (M5a)

This subzone was defined by Berggren and Pearson (2005). Wade et al. 2011 defined this subzone as the biostratigraphic interval between the LO of Praeorbulina sicana and the LO of Praeorbulina glomerosa. In the present study, the Praeorbulina sicana Subzone is represented by the upper part of the Sadat Formation, (samples No.H9 to H13) (Fig.4.4.). Additional events are employed to support the zonal assignment of the upper part of the Sadat Formation to M5a Zone. These are: the co-occurrence of Praeorbulina sicana and Praeorbulina curva.

iii- The Praeorbulina glomerosa LowestOccurrence Subzone (M5b)

The Praeorbulina glomerosa LowestOccurrence Subzone ( M5a) was defined by Berggren and Pearson (2005); Wade et al., 2011 defined this subzone as the biostratigraphic interval between the LO of Praeorbulina glomerosa and the LO of Orbulina suturalis. In the present study, the Praeorbulina glomerosa Subzone is represented by the middle part of the Genefe Formation at Tall Zamzam section, (samples No. T11 and T18) (Fig. 6b). The assignment of the Genefe Formation to P.glomerosa Zone (M5b) is based on the FO of Praeorbulina circularis, Orbulina bilobata and disappearing Orbulina suturalis.

\section{b. Calcareous nannoplankton biozones}

Helicosphaera ampliamperta Zone (NN4) is recorded in the two studied sections. It covers the early (Burdigalian) and Middle (Langhian) Miocene in the studied sections ((Ogg et al., 2016)). Helicosphaera ampliamperta zone (NN4) (Bramlette \& Wilcoxon, 1967, emend.Martini, 1971). The calcareous nannofossil content of the studied succession attributed the Sadat Formation to the Early Miocene and Genefe Formation to the Middle Miocene parts of $H$. ampliaperta Zone NN4. The recognition of $H$. ampliaperta Zone NN4 in the study area was recorded in the Sadat Formation at Wadi Hommath section and the Genefe Formation at Tall Zamzam section (Fig.7). The LO of H. ampliaperta is considered a more reliable marker event for the H. ampliaperta Zone in the Sadat and Genefe formations of the Miocene sections. In Egypt, this zone is equivalent to the $H$. ampliaperta Zone of El- Heiny and Martini (1981), Marzouk (2009), Sadek (2001), Mandur (2009), Faris et al. (2007, 2009), and Soliman et al. (2012).

\subsection{Benthic foraminiferal biofacies}

The distribution of benthic foraminifera was restrained by the environmental conditions (e.g., substrate, salinity, temperature, wave energy, oxygenation, and nutrients) and these conditions are usually depth dependent (Bandy, 1953; Walton, 1964). Thus, it is possible to build a model relating water depth to benthic biofacies (Nyong and Olsson, 1984; Olsson, 1991). This model is a unique tool to interpret environmental changes, for instance deepening and shallowing trends in the studied succession. Moreover, Q-mode cluster analysis on the relative abundance data with a Pearson correlation coefficient using OriginLab Software (http://www.originlab.com/2017) version 2017 is performed (Fig. 4). Consequently, by using Q-mode cluster analysis it was conceivable to classify the samples into biofacies and then recognize which taxa were associated with each biofacies. Accordingly, three biofacies based on the distribution of the benthic foraminifera are recognized in the present study (Fig. 5). These biofacies provided assemblages dominated by 
species that populated inner, middle, to outer neritic environments (Fig. 5).

\section{i. Nonion biofacies}

The Nonion biofacies is represented by $47 \%$ of the benthic faunal variation (Fig. 8). This biofacies has greater percentages of shallow water indicator taxa such as Nonion (17\%) and Elphidium (12\%; Fig. 5). This faunal assemblage indicates that the environment is very shallow, not deeper than a few to a dozen of meters (Murray, 1991; Poag, 1981; Hayward and Brook, 1994; Gonera, 2012; Chan et al., 2017). In the study area, the Nonion biofacies is recorded in samples No. (H9, H10) of the Sadat Formation and samples No. (T17 and T18) of the Genefe Formation (Fig. 8). It is associated with beds containing the highest percentage of siliciclastic sediments (e.g. silty shale, shaly sandstone, and sandy marl; Fig. 8). Otherwise, the average percentage of planktonic foraminifers for samples belonging to this biofacies is $25 \%$. Therefore, this biofacies is the shallowest biofacies ( $\sim 50 \mathrm{~m}$ water depth) of the studied succession, based on the lowest percent of planktonic foraminifera $(25 \%)$ and the coarsest and raised abundances of siliciclastic sediments.

\section{ii. Cibicides biofacies}

The Cibicides is the dominating genus in this biofacies, and is represented by $40 \%$ of the studied forams (Fig. 8). Modern Cibicides is typical of middle neritic environments generally <100 m (Hayward and Brook, 1994; Miller et al., 2008). Miliolina (2\%), Lenticulina (2\%) and Quinqueloculina (6\%) are minor constituents of this biofacies that are typically observed in shallow mid-shelf deposits 0-70 m (Murray, 1973; Murray and Wright, 1974; Boltovskoy and Wright, 1976; Gonera, 2012). This biofacies is represented by $40 \%$ of the benthic faunal variation (Fig. 8b). It is associated with sediments consists of sandy limestone and observed in samples No. H4 and H9 of the middle-upper part of the Sadat Formation (Fig. 8b). The Cibicides biofacies denotes deeper water than the Nonion biofacies based on lithologic and faunal criteria (32\% planktonic foraminifera).

\section{iii. Uvigerina biofacies}

This biofacies is characterized by the rare occurrence of Uvigerina biofacies. It is represented by $8 \%$ of the benthic faunal variation. Furthermore, the Uvigerina biofacies comprises $43 \%$ planktonic foraminifera and has suggested water depth of $\sim 125 \mathrm{~m}$. Moreover, it includes a minor constituent of the benthic faunal assemblages such as Anomalinoides (2\%) and Gyroidinoides (2\%) that are typically found in modern outer neritic deeper environments (van Morkhoven et al., 1986). This biofacies is restricted to the middle part of the Genefe Formation and associated with sediments containing a high percentage of carbonates (e.g. sample No.T10; Fig.). Normally, the Uvigerina is abundant on the outer shelf and the uppermost continental slope (Murray, 1973; Boltovskoy et al., 1980). Consequently, the Uvigerina biofacies is the deepest biofacies represented in the study area $>100 \mathrm{~m}$ water depth (Miller and Lohman, 1982).

\subsubsection{Biostratigraphic integration}

The planktonic foraminifera and nannofossil zonation are integrated to reach to high resolution biostratigraphic scheme from the Miocene stratigraphy. A correlation and age model from analysis of studied calcareous nannofossil and planktonic foraminiferal assemblages for the studied successions.

\section{a. Late Burdigalian Stage}

The Late Burdigalian Stage is defined by two planktonic foraminiferal zones (M4, M5a) which coincide with the calcareous nannofossil zone NN4 (Fig.4.2, 4.4.). It is represented by (9 $\mathrm{m}$ thick.) at the middle part of the Sadat Formation at Wadi Hommath section and it was deposited between (17.26 Ma and 16.97 Ma) at a rate of $(290 \mathrm{~m} / \mathrm{Ma})$.

\section{b. Burdigalian/Langhian stage boundary}

The Burdigalian/Langhian stage boundary is placed at the first appearance of 
Paraeorbulina glomerosa Blow (Iaccarino, 1985; Rögl, 1985; Haggag et al., 1990; Hewaidy et al., 2013). Blow (1969, 1979), Banner and Blow (1965), Ayyad (1983), and Kennett and Srinivasan (1983) placed the Burdigalian/Langhian boundary at the first appearance of Orbulina suturalis Brönnimann 1951. On the basis of calcareous nannofossils, the Burdigalian/Langhian boundary coincides with the Helicosphaera ampliaperta (NN4)/Sphenolithus heteromorphus (NN5) zonal boundary (Fornaciari et al. 1996; Mandur 2009; Sadek 2001; El Deeb et al. 2004; Gradstein et al. 2012). Marzouk (1998) placed the Burdigalian/Langhian boundary at the top of the $H$. ampliaperta (NN4) Zone. This boundary should be placed at the base of the $S$. heteromorphus (NN5) Zone (El-Heiny and Martini 1981). Faris et al. (2007) cited the Burdigalian/Langhian boundary at the base of the Globorotalia fohsi peripheroronda Zone by planktonic foraminifera and within the $H$. ampliaperta Zone (NN4) by calcareous nannofossils. Faris et al. (2009) placed the boundary at the base of the O. suturalis Zone. In the present study, the Burdigalian/Langhian boundary is defined by the FO Praeorbulina circularis Blow1956 at the middle part of the Genefe Formation at Tall Zamzam section.

\section{c. Early Langhian Stage}

The Early Langhian Stage is defined by the planktonic foraminiferal zone (M5b), which coincides with the calcareous nannofossil zone NN4 (Figs.4.3, 4.5.). It is represented by (12 m thick.) of the middle part of the Genefe Formation at Tall Zamzam section. It was deposited between (16.97 Ma and 15.97 Ma) at a rate of $(1 \mathrm{~m} / \mathrm{Ma})$.

\subsection{Sequence stratigraphy}

The integrated high-resolution biostratigraphic studies carried out on the Lower-Middle Miocene sediments in CairoSuez, Egypt provides a framework for sequence stratigraphic interpretation of these sediments. These successions are subdivided into three depositional sequences. The following is the detailed description of these depositional sequences and their sequence boundaries.
Sequence boundary (SB1): it is recorded at the change from the Oligocene sequence to the Lower Miocene Zone M4 of the Sadat Formation at Wadi Hommath section at the first occurrence of Globorotalia semivera Hornibrook,1961. This boundary most probably corresponds to worldwide, short-lived sea-level fall during the Early Miocene at the base of the Globigerinoides bisphericus Zone (Hardenbol et al. 1998; (Ogg et al., 2016). It is a continental erosional surface indicating a break in sedimentation linked with a relative sea-level fall at the top of the the Early Miocene. This sequence boundary is indicated by transition between tectonically stable conditions to rapid subsidence and deep water and may be synchoronous with the world short term-sea level fall which took place at base of M4 Zone (Hardenbol et al. 1998; Miller et al. 2005).

a. Sequence 1: Early Burdigalian Sequence (M1): this depositional sequence includes a single transgressive-regressive depositional sequence at the Lower Burdigalian in the Sadat Formation at Wadi Hommath section (Fig. 9). It is estimated to span CA 0.29 Myr. from $\sim 17.26 \mathrm{Ma}$ at the first occurrence (FO) of Globigerinoides trilobus Reuss, 1850 to $\sim 16.97 \mathrm{Ma}$ (Fig.11). (the sequence boundary at which lithologic features change from coarse sandstone to finer sandy limestone at the first occurrence (FO) of Praeorbulina sicana then transgression tooks place at basal part of the Praeorbulina sicana Zone M5a (Fig. 9).

Transgressive systems tract (TST): it consists of middle to inner shelf brownish red sandy limestone with oysters. The transgressive systems tracts of the studied sequence is assigned to the planktonic foraminiferal zone M4 and the lower part of calcareous nannoplankton zone NN4. It consists of carbonate-clastics alternation package covers the lower Miocene interval from sample No. H1 to sample No. H3. The lower part of this package (sample interval $\mathrm{H} 1-\mathrm{H} 2$ ) is found barren of any foraminiferal content (Fig. 9). Section upwards, in the middle part of the Sadat Formation (sample interval H3-H9), planktonic assemblages are generally rare, the tests are often moderately preserved and the 
most abundant species is Globigerina woodi connecta Jenkins 1964 (Fig. 9). On the other hand, benthic foraminifers occur more frequently, and part of the benthic foraminiferal assemblages are relatively diverse (Fisher's $\alpha$ diversity 6.36 to 8.75 ; Individuals 16 to 22 ; Species No. 3 to 14 , the values of Shannon index $(\mathrm{H})$ in this sample interval declined which indicates an increase of the water depth (Buzas and Gibson, 1969). Furthermore, these sediments are prevailed by Cibicides biofacies (11-19.5\%), that typically observed in shallow mid-shelf deposits 0-70 m (Murray, 1973; Murray and Wright, 1974; Boltovskoy and Wright, 1976; Gonera, 2012) (Fig. 9). Otherwise, the relative abundances of $\mathrm{P} / \mathrm{B}$ ratio (79\%) from the lower middle part of the Sadat Formation (sample No. H3), indicates an outer neritic environment with a water depth of $>100$ $\mathrm{m}$ (Fig.9), whereas the Uvigerina biofacies that a characteristic feature of the outer neritic environment is absent. Therefore, these support the hypothesis that a deepening upward trend occurred within this segment of the section and it probably reflects a Burdigalian transgression during deposition the Sadat Formation.

Maximum flooding surface (MFS): the MFS of this sequence coincides with the top of the fine-grained sand where a bathymetrically deepest interval is recorded. It includes a maximum frequency of planktonic foraminifera (Fig. 9). It is tentatively located at sample No. $\mathrm{H} 3$ in the lower part of the Sadat Formation, where the $\mathrm{P} / \mathrm{B}$ ratio reaches maximum, and expresses the change from inner neritic to outer neritic environments (Fig. 9). It is also synchronous with the MFS recorded in Bur4 sequence of Hardenbol et al., (1998). Furthermore, a tentative age estimate for this MFS is $\sim 17.05 \mathrm{Ma}$ where its placed at the FO of Gds. trilobus (Ogg et al., 2016) (Fig. 11).

Highstand systems tract (HST): it superimposes the MFS and shallowing upward to the overlying sequence boundary (Posamentier et al., 1988). Otherwise, in the present study, the highstand deposits consist of clastics-shale parasequences stacked in a progradational pattern. They make up the middle part of the Sadat Formation (Fig. 9). This part of the sequence is assigned to the planktonic foraminiferal zone M4 and the top part of the calcareous nannoplankton zone NN4 (Fig. 9). The P/B ratio reduces gradually upwards (from 66 to 36), indicating a period of gradual shallowing and progressively decreasing water depth upward. The microfacies types recorded in this package indicate that the sea level retreated upwards from restricted marine platform to shallow inner neritic environment (Fig. 9). Therefore, the upward decreasing in the abundance of the $\mathrm{P} / \mathrm{B}$ ratio and the microfacies types observed in this package provide an additional argument in favor of a shallowing-upward process. As a result, a progradational parasequence set was deposited during a rapid eustatic sea-level rise (Fig. 9).

Sequence boundary (SB2): it occurs between Lower Miocene zones M4 and M5a at the Sadat Formation at the first occurrence of P.sicana Di Stefani,. This boundary most probably corresponds to worldwide, short-lived sea-level fall during the Early Miocene at the top of the Globigerinoides bisphericus Zone (M4) (Hardenbol et al., 1998; Ogg et al., 2016) (Fig. 11).

b. Sequence2: Middle-Late Burdigalian Sequence (M2): it is recorded in the Sadat Formation at Wadi Hommath section and represented by the Middle-Upper Burdigalian Sadat Formation (Fig. 9). It is bounded at the base by the sequence boundary (SB2). It includes a transgressive systems tract (TST).

Transgressive surface: the transgressive surface coincides with the sequence boundary due to rapid relative sea level rise and missing of the lowstand systems tract.

Transgressive systems tract (TST): it falls within the interval of the Praeorbulina sicana (M5a) Zone at the Sadat Formation at Wadi Hommath section (Fig. 9). It is composed of brown to dark brown, hard, argillaceous, fossiliferous and dolomitic limestone. It is characterized by a moderate planktonic/benthic 
ratio (28-36\%), low diversity, and high dominance of the Nonion and Cibicides Biofacies that suggest an inner-middle neritic environments (Fig. 9). 


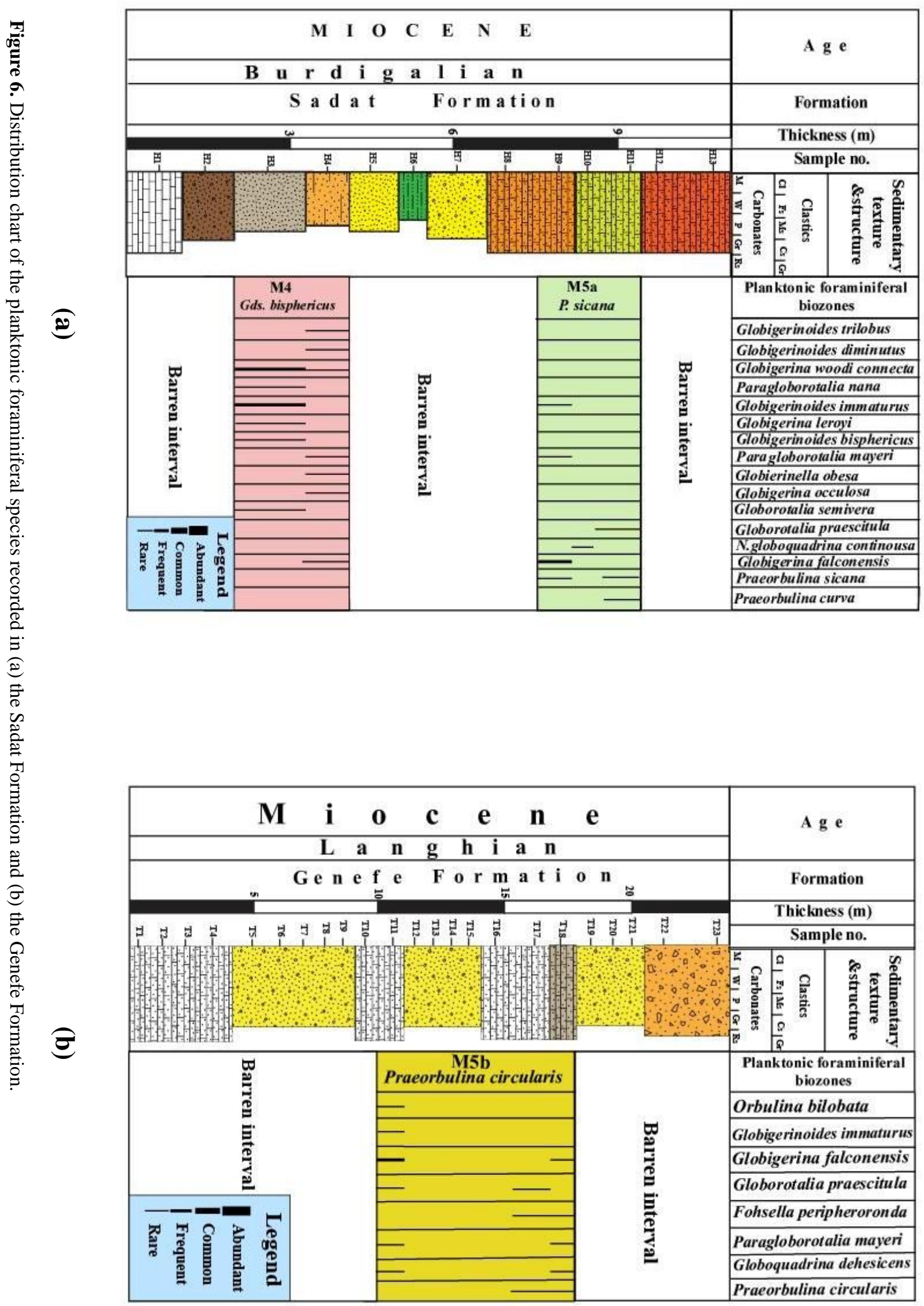




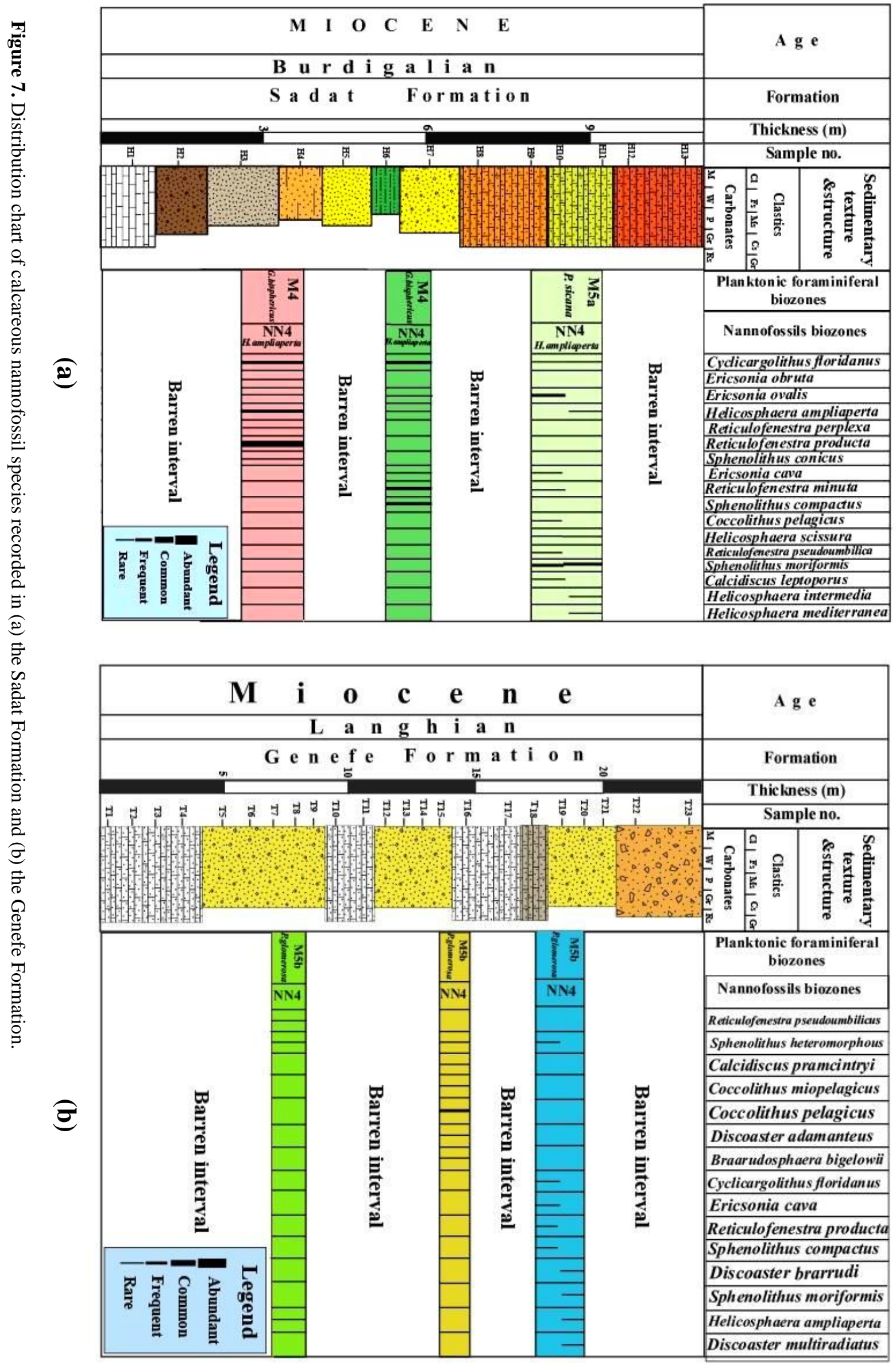




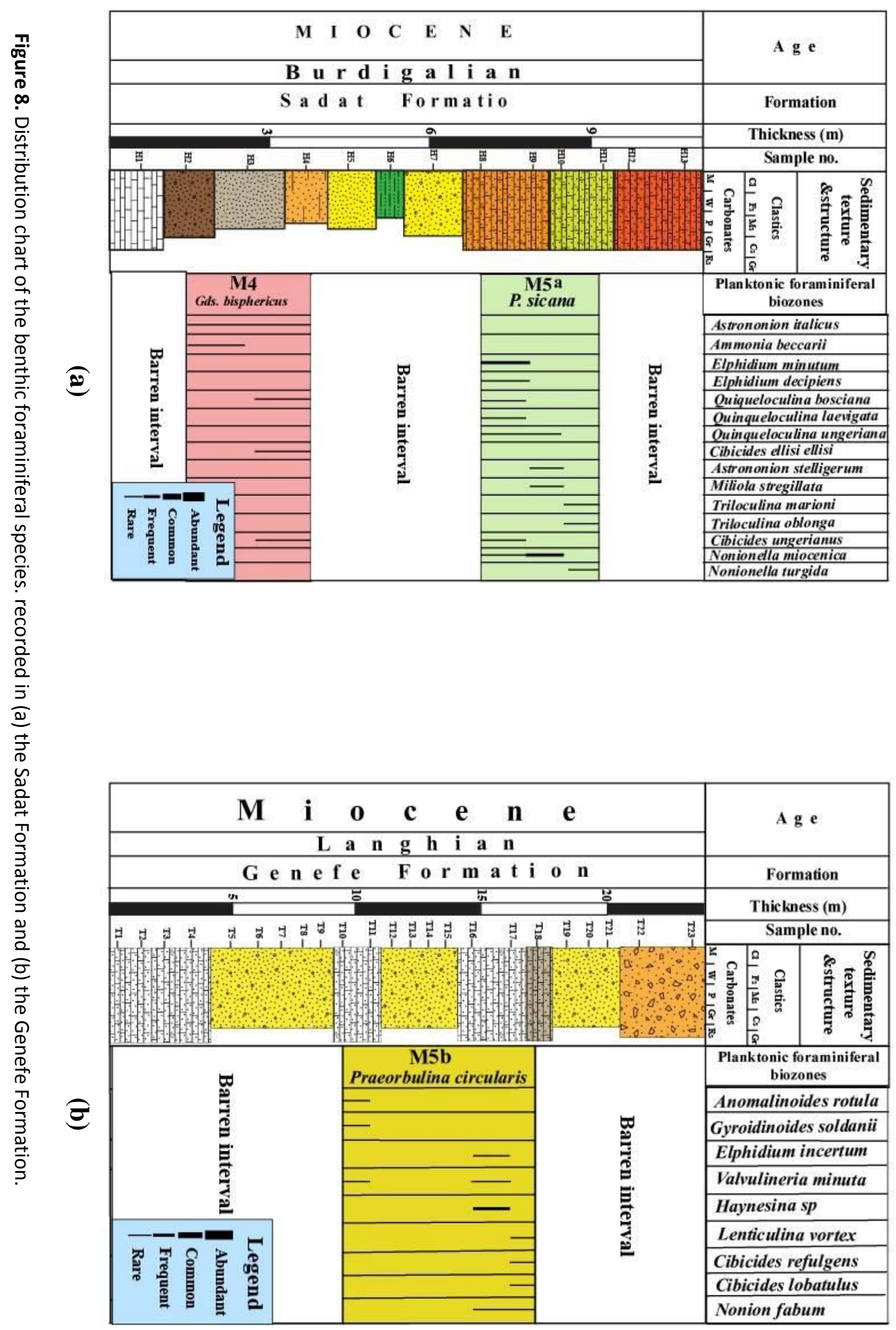


c. Sequence 3: Early Langhian sequence (M3): the third depositional sequence in the Genefe Formation at Tall Zamzam section is attributed to the Early Langhian portion of the Genefe Formation (Fig. 10). This sequence spans CA 0.42 Myr. from $\sim 15.97 \mathrm{Ma}$ at the first occurrence (FO) of Praeorbulina circularis Blow to $\sim 15.55 \mathrm{Ma}$ at the first occurrence (FO) of Reticulofenestra pseudoumbilica Gartner, 1967.

Transgressive systems tract (TST): this tract of this sequence are assigned to planktonic foraminiferal Zone M5b and the lower part of calcareous nannoplankton Zone NN4 (Fig. 10). It consists of carbonate-clastics alternation package covers the early Miocene interval from sample No. T1 to sample No. T11 (Fig. 10). The lower part of this package (sample interval T1-T10) is found barren of any foraminiferal content. Section upwards, in the middle part of the Genefe Formation (sample interval T11T18), planktonic assemblages are generally rare, the tests often moderately preserved and the most abundant species is Globigerina falconensis (Fig.10).
Benthic foraminifera occur more frequently, and part of the benthic foraminiferal assemblages are relatively diverse (Fisher's $\alpha$ diversity 6.18 to 13.19 ; Species No. 4 to 6 ; Fig. $10)$. The values of Shannon index $(\mathrm{H})$ in this sample interval declined which indicates an increase of the water depth (Buzas and Gibson, 1969). Furthermore, these sediments are prevailed by Cibicides biofacies (5.5-27.7 \%), that typically observed in shallow mid-shelf deposits 0-70 m (Murray, 1973; Murray and Wright, 1974; Boltovskoy and Wright, 1976; Gonera, 2012). Otherwise, the relative abundances of $\mathrm{P} / \mathrm{B}$ ratio (77\%) from the lower middle part of the Genefe Formation (sample No. T11), are indicative of an outer neritic environment with a water depth of $>100 \mathrm{~m}$ (Fig. 10). whereas the Uvigerina biofacies that a characteristic of the outer neritic environment is $11 \%$.Therefore, these support the hypothesis that a deepening upward trend occurred within this segment of the section and it probably reflects the Burdigalian transgression of the Genefe Formation.

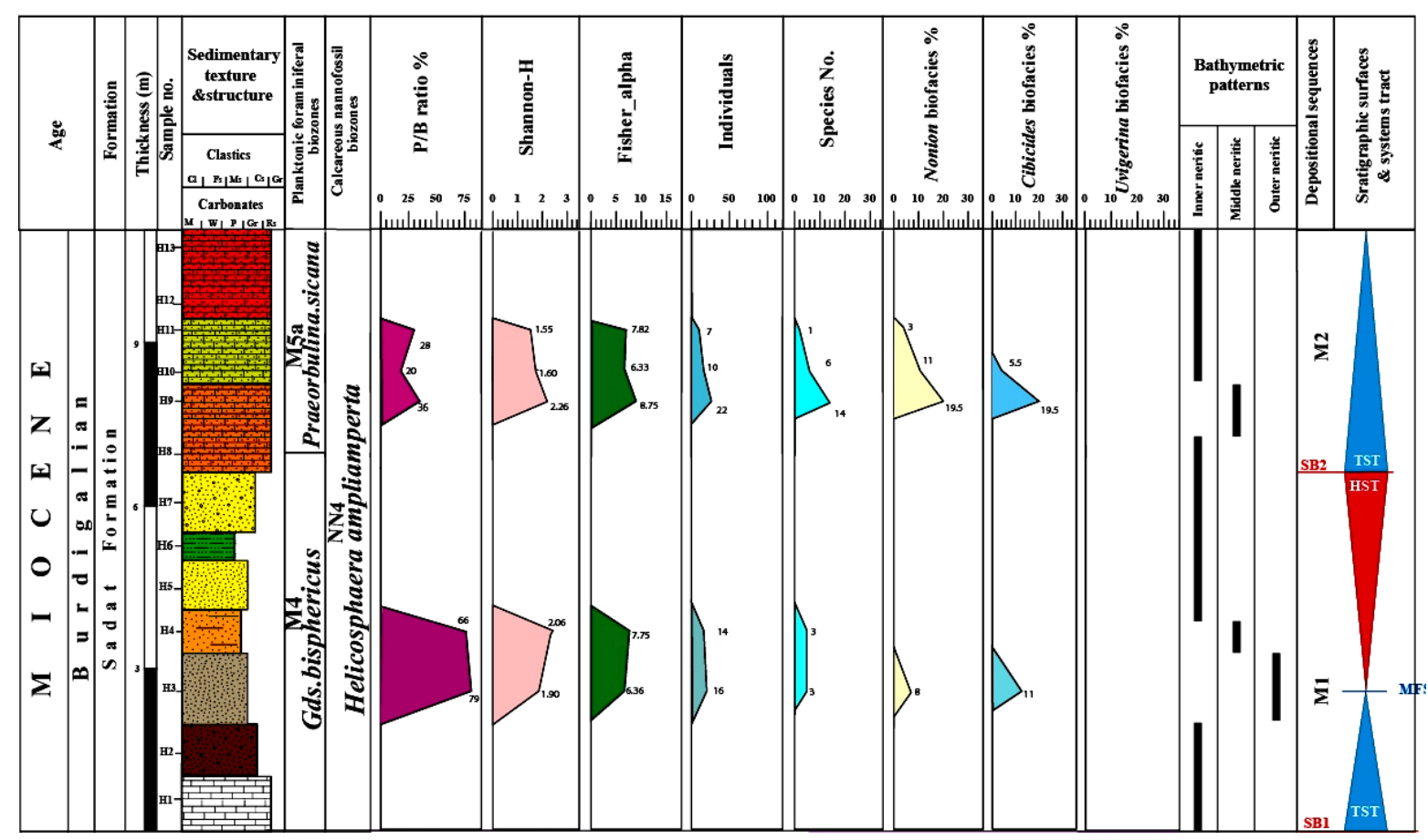

Figure 9. Stratigraphic succession of the Sadat Formation at Wadi Hommath section shows their sequence stratigraphy and eustatic sea level changes. 
Maximum flooding surface (MFS): the MFS of the studied sequence coincides with the top of the fine-grained sandy limestone where the bathymetrically deepest interval and including the maximum frequency of planktonic foraminifera (Fig. 9). It is tentatively located at sample No. T11 in the lower part of the Genefe Formation, where the P/B ratio reaches a maximum, and expresses the change from inner neritic to the outer neritic environments. It is also synchronous with the MFS recorded in Bur5 sequence of Hardenbol et al. 1998. Furthermore, a tentative age estimate for this MFS is $\sim 15.55 \mathrm{Ma}$ where placed at the FO of Reticulofenestra pseudoumbilica Gartner, 1967 (Ogg et al., 2016) (Fig. 11).

Highstand systems tract (HST): it span the systems tract above MFS and shallows upward to the overlying sequence boundary (Posamentier et al., 1988). Otherwise, in the present study, the highstand deposits consist of clastics-carbonate parasequences stacked in the progradational pattern; they make up the upper part of the Genefe Formation (Fig. 10). This part of the sequence is assigned to planktonic foraminiferal Zone M5b and the top calcareous nannoplankton Zone NN4 (Fig. 10). The P/B ratio reduce gradually upwards (from 77 to 30 ), indicating a period of gradual shallowing and progressively decreasing water depth (Fig. 10). the microfacies types that observed in this package are indicate that the sea level retreat upwards from restricted marine platform to shallow inner neritic environments (Fig. 10). Therefore, the upward decreasing in the abundance of the $\mathrm{P} / \mathrm{B}$ ratio and the microfacies types observed in this package provide an additional argument in favor of a shallowingupward process. As a result, a progradational parasequence set was deposited during a rapid eustatic sea-level rise (Fig. 10).

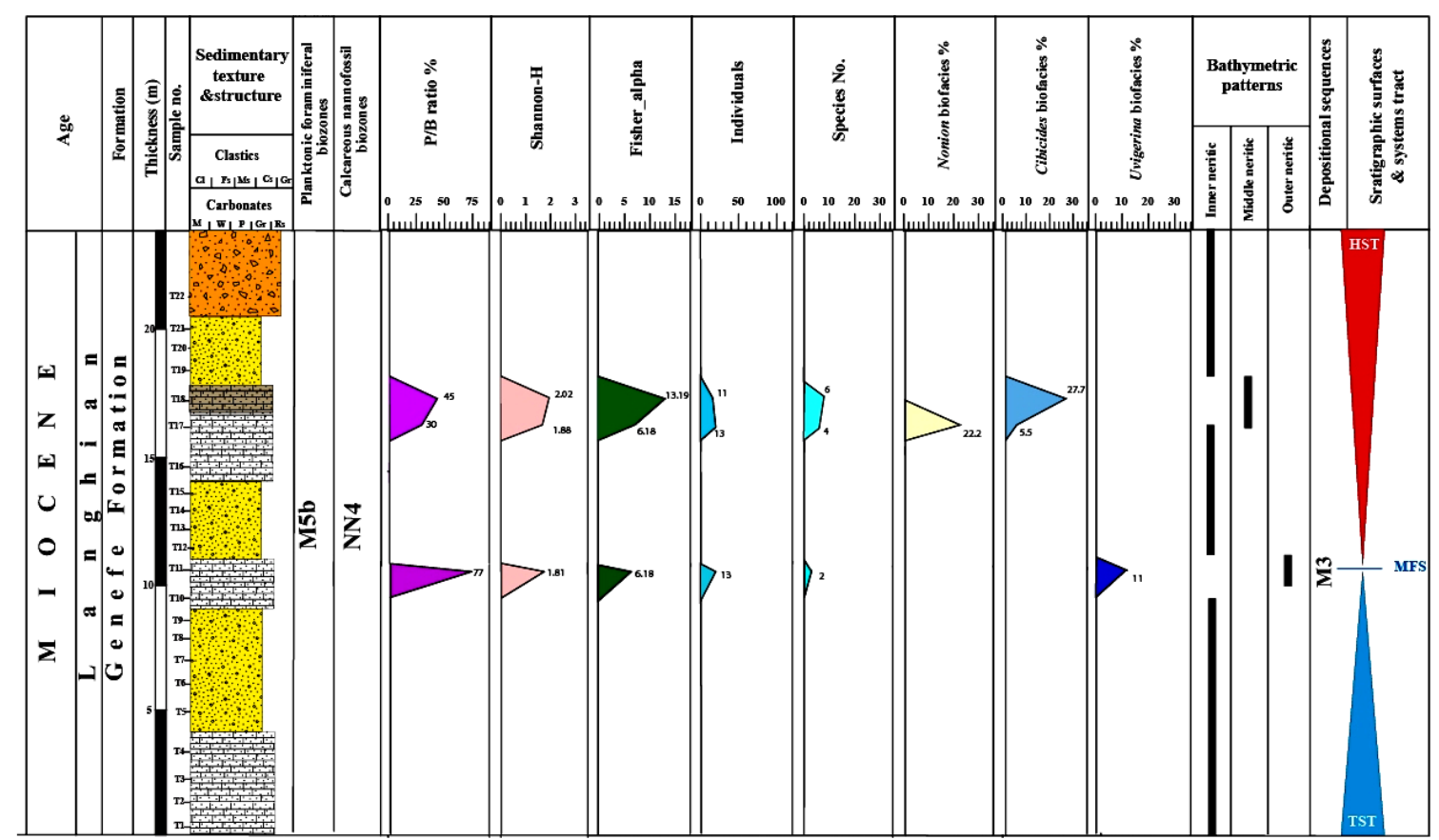

Figure 10. Stratigraphic succession of the Genefe Formation in Tall Zamzam shows their sequence stratigraphy and eustatic sea level changes. 


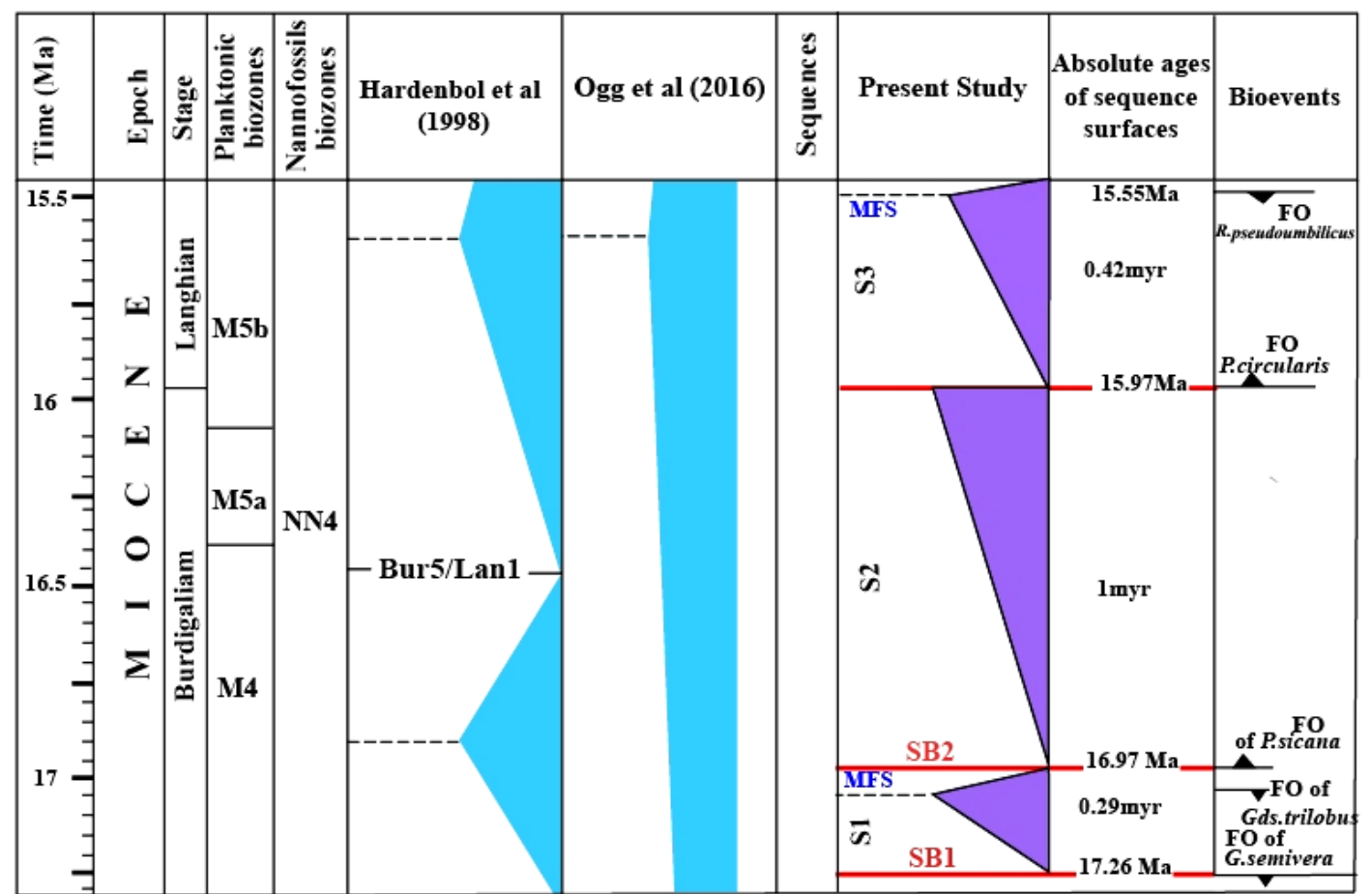

Figure 11. Correlation of the studied Miocene sequence surfaces of the Sadat Formation at Wadi Hommath section and the Genefe Formation at Tall Zamzam section with those of regional studies.

\section{Conclusions}

The Miocene successions in Cairo - Suez district display cyclic sedimentation and relatively rapid lateral facies changes that may be related to deposition on an irregular shelf with submerged structural highs and lows. The microfacies analysis of the studied lower and middle Miocene sections reviled presence of six microfacies types that represented by three carbonate microfacies and three siliciclastic facies types. The identified carbonate microfacies are: 1 . sandy dolostone; 2 . sandy algal bioclastic packstone/grainstone; and 3 . sandy wackestone. Furthermore, the siliciclastic facies types are represented by calcareous quartz arenite, quartz arenite and mudstone reported in the lower part of the Genefe Formation at Tall Zamzam section.

21 species belonging to 9 genera of planktonic foraminifera and 19 species belonging to 10 genera of calcareous nannoplankton are identified. Three planktonic foraminifera are identified. These are: i) Globigerinoides bisphericus Partial-Range Zone (M4); ii) Praeorbulina sicana LowestOccurrence Subzone (M5a); and iii) Praeorbulina glomerosa Lowest-Occurrence Subzone (M5b). The nannofossil biozone Helicosphaera ampliamperta zone (NN4) is also represented in the studied succession. Benthic foraminiferal biofacies are represented by: i) Nonion biofacies; ii) Cibicides biofacies; and iii) Uvigerina biofacies. These benthic foraminiferal biofacies provided assemblages dominated by species that populated inner, middle, or outer neritic environments.

Three depositional sequences corresponding to early - middle Miocene (late Burdigalian- early Langhian) are distinguished. These sequences are: i) Early Burdigalian Sequence (S1) includes a single transgressiveregressive depositional sequence throughout the Burdigalian in the Sadat Formation at Wadi Hommath. ii) Middle-Late Burdigalian 
Sequence (S2 at the Sadat Formation in Wadi Hommath section and includes a transgressive systems tract (TST). iii) Early Langhian sequence (S3) is represented by the Genefe Formation at Tall Zamzam section.

\section{REFERENCES}

Abdallah A.M., Abd El-Hady F.M., (1966): Geology of Sadat area, Gulf of Suez. Journ.Geol., U.A.R. 10(1): 1-22.

Agnini,C., Fornaciari, E., Raffi, I., Catanzariti, R., Pälike, H., Backman, J., Rio, D., (2014): Biozonation and biochronology of Paleogene calcareous nannofossils from low and middle latitudes. Newsletters on Stratigraphy 47(2): 131181, doi: 10.1127/0078-0421/2014/0042.

Ayyad, S.N., (1983): Biostratigraphic studies on subsurface Miocene sediments in North Egypt. Ph. D. Thesis, Geology Department, Mansoura University, $358 \mathrm{p}$.

Bandy, O.L. (1953): Ecology and paleoecology of some California foraminifera; Part I, the frequency distribution of Recent foraminifera off California. J. Paleontol., 27:161-182.

Banner,F.T. and Blow,W.H. (1965): Progress in the planktonic foraminiferal biostratigraphy of the Neogene . Nature. 208 p. 1164-66.

Berggren, W.A., Hilgen, F.J., Langereis, C.G., Kent, D.V., Obradovich, J.D., Raffi, I., Raymo, M.E., and Shackleton, N.J., (1995.): Late Neogene chronology: new perspectives in high-resolution stratigraphy. Geol. Soc. Am. Bull., 107:12721287.

Berggren, W.A, and Peearson, P. N., (2005): A revised tropical and subtropical Paleogene planktonic foraminiferal zonation. Journal of Foram. Res., 35:279-298.

Blow, W.H., (1956): Origin and evolution of the foraminiferal genus Orbulina d'Orbigny. Micropaleontology, 2( 1): $57-70$.

Blow, W. H., (1969): Late Middle Eocene to Recent planktonic foraminiferal biostratigraphy, in Brönnimann, P. and Renz, H. H. (eds), Proceedings of the First International Conference on Planktonic Microfossils: E.J. Brill, Leiden, 1: 199-422

Blow, W.H., (1979): The Cainozoic Globigerinida: Leiden (E.J. Brill), 3: 1412.

Bolli, H.M., (1957a): Planktonic foraminifera from the Oligocene-Miocene Cipero and Lengua formations of Trinidad, B.W.I. In: Studies in Foraminifera, Bulletin of the U.S. National Museum.215: 97-123.

Bolli, H.M., (1957b): Planktonic foraminifera from the Eocene Navet and San Fernando formations of Trinidad, B.W, I., in Loeblich, A. R., Jr., and collaborators, Studies in Foraminifera: U. S. Nat. Mus. Bull. 215: 155-172

Boltovskoy, E., and Wright, R. (1976): Recent Foraminifera. The Haugue, 515p.

Boltovskoy, E. , Giussani, G. , Watanabe, S. and Wright, R., (1980): Atlas of benthic shelf Foraminifera of the Southwest Atlantic. Book 147

Bramlette, M. N., Wilcoxon, J. A., (1967): Middle Tertiary calcareous nannoplankton of the Cipero section, Trinidad, W. I. Tulane Studies Geol., 5: $93-131.0 .0$

Brönnimann, P., (1951): The genus Orbulina d'Orbigny in the Oligo-Miocene of Trinidad, B. W. I. Contributions from the Cushman Foundation for Foraminiferal Research, 2(4): 135.

Buzas, M.A. and Gibson, T.G. (1969): Species diversity: benthonic foraminifera in Western North Atlantic. Science, 163: 72-75.

Chan, S. A., Kaminski, M. A., Al-Ramadan, K., Babalola, L.O., (2017): Foraminiferal biofacies and depositional environments of the Burdigalian mixed carbonate and siliciclastic Dam Formation, Al-Lidam area, eastern province of Saudi Arabia. Palaeog., Palaeoclim., Palaeoec., 469: 122-137.

Cherif, O. H and Yehia, M. A., (1977): Stratigraphy of the area between Wadi Gimal and Wadi Hommath, Gulf of Suez, Egypt. Egypt. J. Geol., 21(2): 185-203.

Clarke K. R., Warwick R. M., (1994): Change in marine communities: an approach to statistical analysis and interpretation. Natural environmental Research Council, Plymouth, UK, 144 pp.

Cushman, J.A. and Bermudez, P.J. , (1937): Further new species of foraminifera from the Eocene of Cuba . Contributions from the Cushman Laboratory for Foram. Res., 13: 1- 29.

Cushman, J.A. and Stainforth,R.M. (1945): The foraminifers of the Cipero Marl Formation of Trinidad, British West Indies . Journ.Foram.Res., 14:1-75.

De Stefani, T. (1950): Su alcune manifestazoni di idrocarburi in provincia di Palermo e descrizione di Foraminifera nuovi: Palermo, Italy (Plinia), 3: p. 9, fig. 6 .

Douglas, R.G. and Woodruff, F. (1981): Deep-sea benthic foraminifera. In: C. Emiliani (Eds.), The Sea, 7, John Wiley, 1233-1327.]

Dunham, R.J., (1962): Classification of carbonate rocks according to the depositional texture, in Ham, W. E., ed., Classification of Carbonate Rocks: A Symposium: Am. Ass. of Petr. Geol., Memoir 1:108-171.

El Deeb, W.Z.M., Elshwah, A. and Mandur M.M., (2004): Planktonic Foraminifera and Calcareous nannoplankton biostratigraphy of the lower and middle Miocene sequence in Wadi Gharandal, southwest Sinai, Egypt. Egyptian Journ. of Petroleum, 13:105-122.

El-Heiny, I. and Martini, E., (1981): Miocene Foraminifera. and calcareous nannoplankton 
assemblages from the Gulf of Suez region and correlation. Geologie Mediterranee, VIII, (2):101108.

El-Sorogy AS, Ziko A (1999): Facies development and environments of Miocene reefal limestone, Wadi Hagul, Cairo-Suez District, Egypt. Neues Jb. Geol. Palaont. Abh., 4:213-226.

Embry, A.F., and Klovan, J.E., (1971): A late Devonian reef tract on northeastern Banks Island: Northwest Territories: Bulletin of Canada. Petr. Geol., 19: 730- 781

Faris, M., Samir, A.M. and Shabaan, M., (2007): Calcareous nannofossil biostratigraphy of the subsurface Miocene sequence, northeast Nile Delta, Egypt. 5th International Conference on the Geology of Africa, 1: 1-31.

Faris, M, Samir, A. M., and Shabaan, M, (2009): Calcareous nannofossil biostratigraphy of the lower and middle Miocene sequence in the Gulf of Suez area, Egypt. 6th Intern. Conf. Geol. Afr., VII: 17- 44.

Flugel, F. (2010): Microfacies of Carbonate RocksAnalysis, Interpretation and Application, Springer, Berlin, Germany.

Fornaciari, E., Di Stefano, A., Rio, D. \& Negri, A. (1996): Middle Miocene quantitative calcareous nannofossil biostratigraphy in the Mediterranean region. Micropaleontology, 42(1): 37-63.

Gartner, S., (1967): Calcareous nannofossils from Neogene of Trinidad, Jamaica, and Gulf of Mexico. Paleontological Contributions. University of Kansas, 29: 1-7.

Ghorab, M. A., and Marzouk, I. M. (1965): A summary report on the rock-stratigraphic classification of the Miocene in the Cairo- Sukhna area. Internal Report, General Petroleum Co., Cairo.

Gonera, M., (2012): Palaeoecology of the Middle Miocene foraminifera of the Nowy Sacz Basin (Polish Outer Carpathians). Geol. Quart., 56 (1): 107-116.

Gradstein, F. M., Ogg, J. G., Schmitz, M. D., and Ogg, G. M., eds., (2012): The Geologic Time Scale 2012: Elsevier, 1: 144 p.

Haggag, M.A. Youssef, I. and Salama, G.R., (1990): Stratigraphic and phylogenetic relationships of Miocene planktonic foraminifera from the Gulf of Suez, Egypt. M.E.R.C, Ain Shams University, Earth Science Series, 4: 22-40.

Hammer, Ø., Harper, D.A.T., Ryan, P.D., (2001): PAST (version 2.02): paleontologycal statistics software package for education and data analysis. Palaeontologia Electronica, 4 (1): 9 pp.

Hardenbol, J., Thierry, J., Farley, M. B., Jacquin, T., de Graciansky, P. C., and Vail, P., (1998): Mesozoic and Cenozoic sequence chronostratigraphic framework of European basins, in Graciansky, P. C. et al. (eds.), SEPM Special Pub. 60: 3-13, charts 1-8.

Hayward, B. W. and Brook, F. J. (1994): Foraminiferal paleoecology and initial subsidence of the early Miocene Waitemata Basin, Waiheke
Island, Auckland. New Zealand Journ. of Geology and Geophysics, 37: 11-24.

Hewaidy, A.A., Farouk, S., and Ayyad, H.M., (2013): Foraminifera and sequence stratigraphy of Burdigalian- Serravallian succession on the eastern side of the Gulf of Suez, southwestern Sinai, Egypt. N. Jb. Geol. Paleont. Abh., 2: 151170.

Hornibrook, N. B. (1961): Tertiary foraminifera from Oamaru district (N.Z.), part. 1. - Systematics and distribution. New Zealand Geo. Sur., Bull. 34: 1192, Pls. 1-28, text-figs. 1-5, tables 1-7.

Iaccarino, S. (1985): Mediterranean Miocene and Pliocene planktonic foraminifera. Plankton Stratigraphy. Cambridge Univ Press: 283-314.

Issawi, B., (2002): Egypt during the Phanerozoic. Geol. Arab World., Cairo Univ., 2: 401-450

Issawi, B., (2005): Archean-Phanerozoic birth and development of the Egyptian land. Geol. Tethys, Cairo Univ., first int. Conf., 2:339-380.

Issawi, B., Francis, M., Youssef, A., Osman, R., (2009): The Phanerozoic of Egypt: a geodynamic approach. Egyptian Geological Survey, Special Publication, 81: 589

Jenkins, D.G., (1964): Globigerina woodi Jenkins subsp. connecta Jenkins, 1964: A new planktonic foraminiferal subspecies from the Australasian Lower Miocene. Micropaleontology, 10(1): +72+.

Kender, S., Kaminski M.A., and Jones, R. W. (2008): Early to Middle Miocene foraminifera from the deep-sea Congo Fan, Offshore Angola. Micropaleontology, 54 (6): 477-568.

Kennett, B.A., and Srinivasan, M.S. (1983): Neogene Planktonic Foraminifera. Hutchinson Ross Publishing Co., Stroudsburg, Pennsylvania, 1-265.

Mandur, M.M., (2004): Stratigraphical and paleontological studies on some Miocene successions of southwest Sinai, Egypt. Unpublished Ph.D. Thesis, Ain Shams University, $1-220$.

Mandur, M.M., (2009): Calcareous nannoplankton biostratigraphy of the lower and middle Miocene of the Gulf of Suez, Egypt. Australian Journ. Basic and Applied Sci., 3(3): 2290-2303.

Martini, E., (1971): Standard Tertiary and Quaternary calcareous nannoplankton zonation. Proceedings of 2nd International Conference on Planktonic Microfossils 2:739-785.

Marzouk, A., (1998): Nannofossil biostratigraphy of the subsurface Miocene sections in the Ras Budran Area, Gulf of suez, Egypt. Neues Jb. Geol. Paläont. Abh., 209 (2): 19-40.

Marzouk, A., (2009): Nannofossil biostratigraphy of Miocene section from two wells in the Gulf of Suez, Egypt. Paleontology, Stratagraphiy, Facies, 532 (17): 101- 127

Miller, K. G., and Lohmann, G. P., (1982): Environmental distribution of Recent benthic foraminifera on the northeast U.S. continental slope. Geological Soc. of America Bulletin, 93(3):200-206. 
Miller, K.G., Hollister, Charles D; Ewing, John I. (2005): Benthic foraminifera abundance of Hole 11-108.

Mount, J., (1985): Mixed siliciclastic and carbonate sediments: a proposed first-order textural and compositional classification: Sedimentology, 32: 435-442.

Murray, J.W., (1973): Distribution and ecology of living benthic foraminifera. Crane, Russak and Co. New York. foraminifera. Longman Sci. Technical, New York, 397 p.

Murray, J.W., (1991): Ecology and palaeoecology of benthonic foraminifera. Longman Scientific Technical, New York, 397 p.

Murray, J.W. and Wright, C.A. (1974): Palaeogene Foraminiferida and palaeoecology, Hampshire and Paris Basins and the English Channel. The Palaeontological Association, London., 14:1-171.

Nyong, E.O., and Olsson, R.K., (1984): A paleo-slope model of Campanian to lower Maestrichtian foraminifera in the North American basin and adjacent continental margin: Marine Micropaleontology, 8:. 437-477.

Ogg, J. G. , Ogg, G. M and Felix M. Gradstein, (2016): A Concise Geologic Time Scale. Elsevier Publ. Co., 234 .

Okada, H., Bukry, D., (1980): Supplementary modification and introduction of code numbers to the low-latitude coccolith biostratigraphic zonation (Bukry 1973, 1975). Marine Micropaleontology 5: 321-325.

Olsson, R.K., (1991): Cretaceous to Eocene sea-level fluctuations on the New Jersey margin: Sedimentary Geology, 70: 195-208.

Osman, R. (2003): New findings in the Eocene stratigraphy of Gebel Ataqa-Northern Galala, North Eastern Desert, Egypt. Egypt.Jour.Sediment., 11:95-109.

Patton, T.L., Moustafa, A.R., Nelson, R.A., Abdine, S.A., (1994): S.M. Tectonic evolution and structural setting of the Suez Rift. In: Landon (Eds.), Interior Rift Basins. American Association of Petroleum Memoir, 59: 9-55.

Phillip, G., Imam, M. M., and Abdel Gawad, G. I. (1997): Planktonic Foraminiferal. biostratigraphy of the Miocene sequence in the area between Wadi El-Tayiba and Wadi Sidri, west central Sinai, Egypt. Journ. Afr. Earth Sci., 25 (3): 435 451.

Pippèrr M. (2011): Characterisation of Ottnangian (middle Burdigalian) palaeoenvironments in the North Alpine Foreland Basin using benthic foraminifera - a review of the Upper Marine Molasse of southern Germany. Mar. Micropaleontol.;79:80-99.

Poag, C.W., (1981): Ecologic Atlas of benthic foraminifera of the Gulf of Mexico: Woods Hole, Massachusetts. Marine Science International, $174 \mathrm{p}$.

Posamentier, H.W., and Vail, P.R., (1988): Eustatic controls on clastic deposition. II-Sequence and systems tract models, in Wilgus, C.K., Hastings,
B.S., Ross, C.A., Posamentier, H.W., Van Wagoner, J.C., and Kendall, C.G.St.C, eds., Sea level changes: An integrated aroach: Soc. of Economic Paleontologists and Mineralogists, Special Publication 42: 125-154.

Reuss, A.E. (1850): Newe foraminiferen aus den Schichten des Ostrerreischen Tetiarbecken. Koeniglich Akademie der Wissenschaften. Wien, Klasse. - Denkschriften, 1: 365-390.

Rögl, F., (1985): Late Oligocene and Miocene planktonic foraminifera of the central paratethys. In : Bolli, H.M., Saunders, J.B. and PerchNeilsen, K. (eds.) Plankton Stratigraphy. Cambridge Univ. Press, 315-328.

Sadek, S., (2001): Biostratigraphic contribution to the Miocene formations (Gharandal Group), north Hammam Faraun area, Sinai Egypt. J.Paleon., 1:253-261.

Said, R., (1990): Cenozoic. In: Said, R. (Ed.), The geology of Egypt. A.A. Balkema, Rotterdam, 451-486.

Soliman, A., Stjepan C'oric', Martin J. H., Werner E. P. and El Beialye Y.E., (2012): Lower and Middle Miocene biostratigraphy, Gulf of Suez, Egypt based on dinoflagellate cysts and calcareous nannofossils. Palynology, 36 (1): 38-79.

Steckler, M., Berthelot, F, Lyberis, N., Le Pichon, X., (1988): Subsidence in the Gulf of Suez implications from rifting and plate kinematics. Tectonophysics, 153:249-270.

Strougo, A. and Faris., M. (2008): Eocene calcareous nannofossil biostratigraphy of Egypt. The NP18/NP19 zonal boundary: fact or fiction? Egypt. Journ. Paleon., 8: 149-168.

Todd, R. and Post, R., (1954): Smaller Foraminifera from Bikini drill holes. U.S., Geological Survey, 260:547-568.

Van Morkhoven, F.P.C.M., Berggren, W.A., and Edwards, A.S., (1986): Cenozoic cosmopolitan deep-water benthic foraminifera. Bull. Cent. Rech. Explor.-Prod. Elf-Aquitaine, Mem. 11:1-423.

Wade, B. S., Pearson, P. N., Berggren, W. A., Palike, H., (2011): Review and revision of Cenozoic tropical planktonic foraminiferal biostratigraphy and calibration to the geomagnetic polarity and astronomical time scale. EarthScience Reviews 104:111-142. doi:10.1016/j.earscirev.2010.09.003

Walton, W.R., (1964): Recent foraminiferal ecology and paleoecology, in Imbrie, J., and Newell, N., eds., Approaches to paleoecology: New York, John Wiley:151-237.

Wilson, J.L., (1975): Carbonate Facies in Geologic History: New York, Springer-Verlag, 469 p. 


\section{الملخص الغربي}

يوجد قطاعين من الميوسين علي طريق القاهرة السويس، مصر تمت عليهم الدراسه وهما تل زمزم وو ادي حومص ، حيث سجل متكون السادات فى قطاع و ادى حومص وسجل متكون جينيفه فى قطاع تل زمزم سته وثلاثون عينه جمعت وحللت لمعرفه محتو اها الحفرى من الفور امينيفر او النانو بلانكتون حيث أمكن التعرف على هي

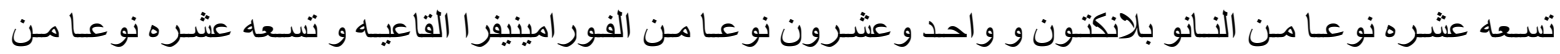
الفور امينيفر ا الطافيه .

أتاحت دراسـة المحتوي الحفري تقسيم تتابع الميوسين السفلي و الاوسط بطريق القاهرةـ السويس الي ثناثــ Zone (M4)، نطاقات من الفور امنيفر ا القاعيه و نطاق و احد من النلانوبلانكتون. هي من الاقدم الي الاحدث كالتالي (Zone (M5a) Praeorbulina Burdigalian ) عمره الميوسين السفلي Globigerinoides bisphericus sicana Helicosphaera ) Zone (NN4 (Langhian) (ampliaperta در اسه محتوي الفور امينيفر ا الطافيه حقق الحصول على ثلاثهـ تجمعات بيئيه ، للحفريات تبعا لبيئه الترسيب

و هى (Nonion biofacies) التى تترسب فى بيئة جنوب شـاطئيه حتى عمق متر • 0, (Cibicides biofacies)

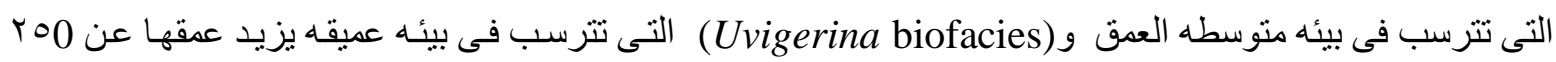
وقد تم تعريف سته قطاعات من القطاعات الرقيقة لهذه الصخور ادت الى ان هذه المتكونات ترسبت فى مـا بين بيئة بحرية ضحلة وبيئة بحرية عميقة. كما امكننا تقسيم هذا التتابعات الطبقيه للقطاعا التتابع المدروس الى ثلاثه انواع من التتابعــــــات الطباقيه الترسيبيه

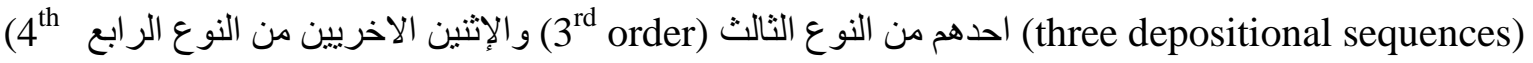

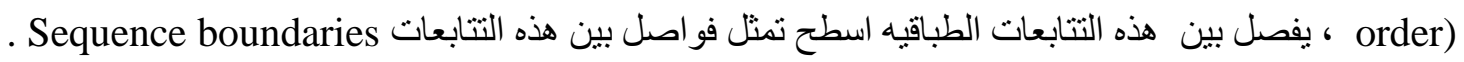

